DOI: $10.17951 /$ lrp.2020.39.1.201-218

\author{
BARBARA KALINOWSKA-WITEK \\ Uniwersytet Marii Curie-Skłodowskiej \\ ORCID - 0000-0002-4417-1675
}

\title{
TROSKA O ZDROWIE \\ I PRAWIDŁOWY ROZWÓJ FIZYCZNY DZIECI \\ NA ŁAMACH CZASOPISMA „ŻYCIE DZIECKA” \\ Z LAT 1932-1937
}

\begin{abstract}
Streszczenie: Celem artykułu jest ukazanie poglądów publicystów czasopisma „Życie Dziecka” (1932-1937) na temat potrzeby otoczenia opieką dzieci z rodzin najuboższych. W celu zgromadzenia danych zastosowano metodę analizy zawartości prasy. „Życie Dziecka” było to „czasopismo poświęcone ochronie macierzyństwa, opiece nad dziećmi i młodzieżą i życiu dziecka”. Ukazywało się w latach 30. XX wieku. Odrodzone po 123 latach niewoli Państwo Polskie wciąż było zacofane gospodarczo i zróżnicowane społecznie. Dodatkowo światowy kryzys gospodarczy spowodował pogorszenie warunków materialnych znacznej części społeczeństwa. W najtrudniejszej sytuacji znalazły się dzieci z warstw najuboższych - robotniczych i chłopskich. Niedożywione, zaniedbane, ciężko pracujące w gospodarstwie, słabo rozwinięte pod względem fizycznym, często chore, potrzebowały pomocy. Rodzice nie mieli możliwości zaspokojenia ich potrzeb, należało więc zaangażować szersze kręgi społeczne i zorganizować niezbędne wsparcie. Zagadnienia te poruszano na łamach czasopism, starano się uświadomić społeczeństwu konieczność zorganizowania opieki i wsparcia dla najbardziej potrzebujących. Pisano też o podejmowanych w tym zakresie działaniach.
\end{abstract}

Słowa kluczowe: opieka nad dziećmi, kolonie letnie dla dzieci, opieka społeczna, zagrożenie rozwoju dzieci

\section{WPROWADZENIE}

Prawidłowy rozwój fizyczny ułatwia funkcjonowanie człowieka w życiu. Nie jest gwarantem szczęścia jednostki, jednak deficyty rozwojowe poważnie utrudniają, a czasami wręcz uniemożliwiają realizację obowiązków szkolnych, rodzinnych 
i zawodowych, są przyczyną cierpienia i frustracji jednostki. Dlatego tak ważne jest zadbanie o zdrowie człowieka już od pierwszych chwil jego życia oraz stworzenie warunków dla prawidłowego rozwoju. Warunki te zależą w dużym stopniu od kondycji państwa i sytuacji społeczno-ekonomicznej rodziny. Lata 30. XX wieku były szczególnie trudnym okresem dla znacznej części mieszkańców Rzeczypospolitej. Wprawdzie już od kilkunastu lat Polska cieszyła się niepodległością, ale odrodzone państwo nie poradziło sobie jeszcze z wieloma problemami, zwłaszcza socjalnymi. W 1923 roku weszła w życie ustawa o opiece społecznej. ${ }^{1}$. Wyróżniono w niej różne kategorie osób, którym przysługiwały świadczenia opieki ze strony państwa i powołanych w tym celu instytucji. Na przeszkodzie w realizacji działalności opiekuńczej i pomocowej stanęły jednak trudności materialne, spowodowane okresem wieloletniej niewoli i zacofania gospodarczego, a następnie w latach 1929-1933 światowym kryzysem gospodarczym. Tymczasem pomocy i wsparcia potrzebowały zwłaszcza warstwy najuboższe, a szczególnie dzieci². Opieka społeczna nie funkcjonowała na wystarczającym poziomie, ponadto podejmowane działania nie zawsze przynosiły zamierzone rezultaty ${ }^{3}$. Dlatego zastanawiano się, jak przezwyciężyć problem ubóstwa i jego negatywne konsekwencje $4^{4}$. Lekarze, pedagodzy oraz działacze społeczni na łamach czasopism niejednokrotnie wypowiadali się na temat zagrożeń występujących w życiu społecznym oraz sposobów ich przezwyciężania.

W omawianym okresie ukazywały się różne czasopisma, zajmujące się zagadnieniami opieki i wychowania dzieci oraz młodzieży. Jednym z nich był miesięcznik „Życie Dziecka: czasopismo poświęcone ochronie macierzyństwa, opiece nad dziećmi i młodzieżą i życiu dziecka”. Podtytuł sytuował go wśród pism, zwracających szczególną uwagę na zagadnienia opieki. Periodyk ukazywał się w latach 1932-1937. Stanowił kontynuację wydawanego od 1923 roku dwumiesięcznika „Opieka nad Dzieckiem”. Od 1 stycznia 1938 roku zmieniono tytuł pisma na „Życie Młodych”. Czasopismo wydawano nakładem Polskiego Komitetu Opieki nad Dzieckiem. Obowiązki redaktora aż do 1936 roku pełnił dr Jerzy Michałowicz. W czasopiśmie funkcjonowały działy: „Artykuły”, „Zagadnienia wychowawcze”, „Kronika krajowa”, „Kronika zagraniczna”, „Przegląd piśmiennictwa”, „Przegląd prasy pedagogicznej”, Nadesłane. W 1935 roku dodano rubrykę: „Lecznictwo i wychowanie sanatoryjne".

${ }^{1}$ Ustawa z dnia 16 sierpnia 1923 roku o opiece społecznej, Dz. U. 1923, nr 92, poz. 726.

2 M. Balcerek, 1978, Rozwój opieki nad dzieckiem w Polsce w latach 1918-1939. Warszawa.

${ }^{3}$ Ł. Kabzińska, K. Kabziński, 2012, Wybrane aspekty zagrożonego dzieciństwa w dwudziestoleciu międzywojennym. „Warmińsko-Mazurski Kwartalnik Naukowy. Nauki Społeczne”, nr 4, s. 11-43.

${ }^{4}$ Opieka nad młodzieża i dziećmi, 1926, „Praca i Opieka Społeczna”, z. 1-2, s. 65.

${ }^{5}$ M. Michałowicz, 1932, Na nowe drogi. „Życie Dziecka”, nr 1, s. 1-2.

${ }^{6}$ Redakcja i Administracja, Zmiana tytułu „Życia Dziecka”, „Życie Dziecka” 1937, nr 11, s. 224. 
W artykułach zamieszczanych w poszczególnych działach poruszano zagadnienia: ochrony macierzyństwa, opieki nad niemowlętami, dziećmi w wieku przedszkolnym i szkolnym, nad młodocianymi, opieki nad sierotami, dziećmi opuszczonymi i „występnymi”, nad „słabowitymi, chorymi i ułomnymi”. Analizowano też zagadnienia dotyczące zdrowia oraz wychowania fizycznego dzieci i młodzieży. Problematykę tę prezentowano nie tylko w odniesieniu do terenu Rzeczypospolitej, ale też innych krajów europejskich i Stanów Zjednoczonych? Pokazanie rozwiązań stosowanych w państwach ościennych miało na celu wskazanie możliwości rozwijania różnych form opieki nad potrzebującymi w Polsce, ale też stanowiło przestrogę i wskazówkę, jakich błędów i w jaki sposób należy unikać.

Jednym $\mathrm{z}$ ważniejszych zagadnień poruszanych $\mathrm{w}$ czasopiśmie była troska o poprawę stanu zdrowia społeczeństwa, a zwłaszcza najmłodszych obywateli. Publicyści pisma, wśród których znaczną grupę stanowili lekarze, zwracali uwagę, że na zdrowie dziecka wpływa wiele różnorodnych czynników. Podkreślali znaczenie okresu dzieciństwa, a zwłaszcza pierwszych lat życia. Wskazywali na związek kondycji niemowlęcia ze stanem zdrowia i kondycją fizyczną jego matki. W związku z tym podkreślali konieczność objęcia opieką nie tylko dzieci i młodzieży, ale również kobiet ciężarnych oraz młodych dziewcząt, które za kilka lat miały zostać matkami. Zwracali też uwagę na potrzebę zapewnienia właściwej opieki matkom, wychowującym małe dzieci.

\section{OPIEKA NAD MATKĄ I NIEMOWLĘCIEM}

Troska o zdrowie matek $\mathrm{z}$ warstw najuboższych i ich nowo narodzonych dzieci była niezmiernie ważna, stanowiła jednocześnie istotny problem społeczny. Bardziej świadomi działacze społeczni i publicyści domagali się z jednej strony podjęcia działań uświadamiających społeczeństwu zagrożenia, jakie niosły niewłaściwe warunki życia dzieci w rodzinach najuboższych, z drugiej zaś zapewnienia matkom i ich dzieciom niezbędnej pomocy i wsparcia. W realizacji tych działań mogły pomóc czasopisma, a szczególnie miesięcznik „Życie Dziecka”. Redakcja i publicyści pisma podjęli i w kolejnych latach realizowali to zadanie, zwracając uwagę zwłaszcza na konieczność większego uświadomienia kobiet z warstw najuboższych na temat właściwej opieki nad dzieckiem. Lila Friedlanderowa w jednym $z$ artykułów informowała czytelniczki, jak ważny jest stały rozkład

7 Poradnie odżywcze i ochronki. ZSRR, 1936, „Życie Dziecka”, nr 4, s. 127; Opieka nad macierzyństwem szwankuje. ZSRR, 1937, „Życie Dziecka”, nr 1, s. 28; Opieka nad matka i dzieckiem. Anglia, 1937, „Życie Dziecka”, nr 4, s. 128; Stan fizyczny dzieci w szkołach londyńskich, 1937, „Życie Dziecka”, nr 1, s. 28. 
dnia w życiu małego dziecka oraz regularne i systematyczne odżywianie. Pisała: „Usystematyzowanie snu i posiłku dziecka - co wygląda, ale tylko wygląda, raczej na tresurę niż wychowanie - jest pierwszym zadaniem matki wobec małego dziecka, jest pierwszym warunkiem korzystnego rozwoju cielesnego, a zwłaszcza nerwowego, ale jest także pierwszym zadatkiem dobrego wychowania"8. Również mycie, ubieranie, zabawa, spacery powinny odbywać się w stałej, określonej porze. Autorka podkreślała, że w wychowaniu chodzi „nie o bierne higieniczne chowanie dziecka, jak to ma miejsce w większości wypadków, ale o wychowanie do czynnego, higienicznego trybu życia na ten czas, kiedy już wyjdzie spod opieki matczynej. Środki do tego: systematyczność, konsekwencja i czynne wciagnięcie dziecka do wychowania higienicznego" ". Aby matki popełniały mniej błędów w wychowaniu, należy je fachowo przygotowywać do macierzyństwa, np. poprzez udział w szkoleniach $^{10}$. Ks. Franciszek Cieszyński postulował, aby o zdrowie matek i dzieci na wsi troszczyły się położne, które będą przygotowywać młode kobiety do właściwej opieki nad potomstwem ${ }^{11}$.

Również Jan Bogdanowicz podkreślał koniczność przygotowania matek do ich obowiązków rodzicielskich. Pisał o schorzeniach dziedzicznych, chorobach przewlekłych rodziców - alkoholizmie, gruźlicy, chorobach wenerycznych, chorobach matki w ciąży oraz o innych szkodliwych czynnikach, do których zaliczał: głód, ciężką pracę młodych dziewcząt, wyniszczenie organizmu, przemęczenie. Podkreślał negatywny wpływ tych czynników na zdrowie potomstwa. Przekonywał czytelniczki: „Lepiej, żeby się dzieci rodziły silne i zdrowe - wtedy lepiej zniosą one ciężkie warunki otaczającego ich życia. Z chorowitego i wyniszczonego noworodka późniejsze wysiłki nie zrobią łatwo znowu zdrowego i silnego dziecka i koszt oraz wysiłek będzie znacznie większy. Statystyka śmiertelności niemowlęcej i małego dziecka jest nie tylko wyrazem nieumiejętności wychowywania dzieci i nieuświadomienia higienicznego matek, ale i wyrazem ciężkich warunków okresu macierzyństwa"12. Wskazywał, że trzeba uczyć kobiety, jak powinny zachowywać się w okresie ciąży, gdyż nie tylko trudne warunki socjalne i ekonomiczne źle wpływają na dziecko, ale też lekkomyślność czy nieświadomość matek. Powodem problemów mógł też być ciężki poród wynikający z nieprawidłowej budowy kobiety, złego ułożenia płodu czy niewłaściwych warunków, w jakich się on od-

${ }^{8}$ L. Friedlanderowa, 1934, Błędy wychowawcze matek. „Życie Dziecka”, nr 10-11, s. 311.

9 Tamże, s. 312.

10 Tamże.

${ }^{11}$ F. Cieszyński, 1933, Położna jako wiejska opiekunka zdrowia matki i dziecka. „Życie Dziecka”, nr 9, s. 242.

12 J. Bogdanowicz, 1934, Opieka nad dzieckiem do jego urodzenia. „Życie Dziecka”, nr 10-11, s. 308 . 
bywał. Dlatego Jan Bogdanowicz sądził, że potrzebna jest „opieka społeczna oraz uświadomienie społeczeństwa o konieczności racjonalnego zabezpieczenia aktu porodu"13. Inny publicysta zwracał uwagę, że zbyt częste ciąże wyniszczają organizm kobiety i negatywnie odbijają się na zdrowiu potomstwa, są też przyczyną wysokiej umieralności niemowląt ${ }^{14}$.

O błędach popełnianych przez matki niemowląt i małych dzieci na wsi donosił Czesław Piekarski, kierownik Powiatowej Stacji Opieki nad Matką i Dzieckiem w Śremie. Zwracał uwagę na ciężką pracę młodych dziewcząt i kobiet mieszkających na wsi, a zwłaszcza na ciężką pracę położnic wkrótce po porodzie, niewłaściwe żywienie dziecka, rzadkie kąpanie, przebywanie maleństwa w dusznych pomieszczeniach. Pisał: „Każda matka daje dziecku to, co uważa za dobre. Mleko z zasady daje się zbyt rozcieńczone: $1 / 3$ mleka i $2 / 3$ wody, cukru albo za mało, albo za dużo. Często w pierwszym lub drugim miesiącu życia daje się dziecku rozmaite kaszki, zupki, a nawet bułki i chleb. Tego co potrzeba, dziecko nie dostaje wcale, ani jarzyn, ani owoców, ani soków owocowych, w zimie chroni się go starannie przed każdym powiewem świeżego powietrza, trzymając miesiącami w dusznej, wilgotnej i ciemnej izbie, nigdy nie przewietrzanej, gdyż żałuje się ciepła, a często dla oszczędności ram i okuć okna są wprawione na głucho i w ogóle nie można ich otworzyć. Dziecko kąpie się rzadko, pieluszki po zmoczeniu tylko się suszy i używa ponownie. Stąd też największa śmiertelność wśród niemowląt panuje właśnie na wsi, a wyjątkiem jest niemowlę zupełnie zdrowe. Dzieci na wsi bardzo często chorują na zaburzenia trawienia, choroby skórne, a już prawie każde dziecko przechodzi krzywicę w większym lub mniejszym nasileniu. W wieku od 7-8 miesięcy przechodzi dziecko na pożywienie dorosłych"15. Piekarski ubolewał jednocześnie nad zniesieniem od 1 listopada 1933 roku obowiązku przynależności ludności zajmującej się rolnictwem do kas chorych. W Poznańskiem przynależność do tych kas wciąż była obowiązkowa, co ułatwiało dostęp do lekarza i nieco łagodziło ciężkie warunki życia dziecka i matki w środowisku wiejskim. Dlatego Piekarski domagał się utworzenia ubezpieczalni społecznych dla matek i dzieci zamieszkałych na wsi, które to instytucje opłacałyby lekarzy stacyjnych, przyjmujących pacjentów w określone dni tygodnia ${ }^{16}$.

W 1931 roku, w okresie gdy periodyk ukazywał się jeszcze pod nazwą „Opieka nad Dzieckiem”, ogłoszono w nim konkurs na pogadankę dla rodziców na temat żywienia dzieci. W kwietniu 1932 roku w pierwszym numerze „Życia Dziecka” zamieszczono dwie nagrodzone w tym konkursie pogadanki, autorstwa Siostry

\footnotetext{
13 Tamże, s. 309.

14 Wiek matki i okresy czasu między kolejnymi porodami, 1936, „Życie Dziecka”, nr 1, s. 30.

15 C. Piekarski, 1934, Opieka społeczna nad matką i dzieckiem na wsi. „Życie Dziecka”, nr 6, s. 171.

16 Tamże, s. 172-174.
} 
M. ${ }^{17}$ i Marii ${ }^{18}$. W obu pracach autorki podkreślały konieczność uświadamiania rodzicom, zwłaszcza matkom, zasad prawidłowej opieki nad niemowlęciem. Kilka lat później, w jednym z numerów czasopisma z 1936 roku, publicysta informował czytelników o szkoleniu dla rodziców, organizowanym w Stanach Zjednoczonych Ameryki Północnej, które dotyczyło prawidłowego odżywiania dzieci. Wyraził przekonanie, że również u nas takie kursy przyniosłyby społeczeństwu wiele korzyści ${ }^{19}$. W 1937 roku na łamach „Życia Dziecka” informowano o otwarciu w Warszawie pierwszych w Polsce trzymiesięcznych kursów dla kobiet, dotyczących ich obowiązków w rodzinie - obejmowały one m.in. zajęcia z zakresu higieny, ratownictwa, pielęgnacji niemowląt, pielęgnacji chorych, odżywiania dzieci i dorosłych oraz osób chorych, higieny psychicznej, organizacji zajęć domowych ${ }^{20}$. Zaznajomiono też czytelników z projektem ustawy o opiece nad macierzyństwem, dziećmi i młodzieżą. Opieka ta miała być realizowana dla wszystkich kategorii podopiecznych w czterech formach: opieki zdrowotnej (świadczeń higieniczno-leczniczych), opieki moralnej (zapobieganie zagrożeniom), opieki materialnej (zapewnienie godziwych warunków życia) oraz opieki prawnej (ochrona dziecka i pomoc prawna dla młodzieży oraz rodziców) ${ }^{21}$.

W celu poprawy sytuacji zdrowotnej w warstwach najuboższych Polski Komitet Opieki nad Dzieckiem zakładał w różnych miastach i miasteczkach Stacje Opieki nad Matką i Dzieckiem, w których kobiety i ich dzieci mogły uzyskać niezbędną pomoc. W 1932 roku redakcja czasopisma ogłosiła konkurs dla rodziców, w którym mogli oni wypowiedzieć się na temat: „Co daje stacja opieki matce i dziecku”22. Nagrodzone prace publikowano w kolejnych numerach czasopisma, o działalności stacji opieki informowano też w następnych latach ${ }^{23}$. W numerze $4 \mathrm{z} 1932$ roku pisano, że w dziesiątą rocznicę powstania pierwszej Stacji Opieki nad Matką i Dzieckiem na ziemiach polskich funkcjonowało 400 takich placówek. Ich celem było propagowanie racjonalnego wychowania dzieci. Apelowano do czytelników:

17 Siostra M., 1932, Po co przychodzę z dzieckiem do poradni. „Życie Dziecka”, nr 1, s. 27-39.

18 Maria, 1932, Pogadanka o odżywianiu niemowlęcia. „Życie Dziecka”, nr 1, s. 40-52.

19 Eksperyment dotyczacy szkolenia rodziców w pojmowaniu zagadnień odżywiania dzieci (St. Zjedn.), 1936, „Życie Dziecka”, nr 4, s. 127.

${ }^{20}$ Kurs p.n. „Kobieta $w$ rodzinie”, 1937, „Życie Dziecka”, nr 3, s. 87.

${ }_{21}$ Zob. Prace nad ustawa o opiece nad macierzyństwem, dziećmi i młodzieża, 1936, „Życie Dziecka", nr 8-9, s. 233. Projekt ten stanowił rozwinięcie ustawy z dnia 16 marca 1923 roku o opiece społecznej. Niestety, nigdy nie wszedł w życie.

${ }^{22}$ Konkurs na pogadankę z rodzicami: Co daje stacja opieki matce i dziecku, 1932, „Życie Dziecka”, nr 1, s. 53-54.

${ }^{23}$ E. Stoffowa, 1932, Powstanie, organizacja i praca Stacji Opieki nad Matka i Dzieckiem we Lwowie. „Życie Dziecka”, nr 3, s. 125; Z działalności Stacji Opieki nad Matka i Dzieckiem w Chełmży z roku 1931, 1932, „Życie Dziecka”, nr 2, s. 94-95; Nowa Stacja Opieki nad Matka i Dzieckiem w Sosnowcu, 1937, „Życie Dziecka”, nr 1, s. 20. 
„Dziś [...] państwo nasze jest wciąż jeszcze krajem o największej śmiertelności niemowląt. Przy nieomal największym przyroście naturalnym w Europie, jesteśmy jednocześnie krajem, w którym śmiertelność dzieci, zwłaszcza w rodzinach licznych i ubogich, osiąga potworny stosunek 50\%. Śmiało rzec można, że matki ubogie w Polsce rodzą dzieci dotąd tylko po to, aby je pochować. W tych warunkach opieka nad dzieckiem w Polsce musi stać się jednym z najdonioślejszych zadań i obowiązków całej myślącej części naszego społeczeństwa" ${ }^{\text {"2 }}$. Artykuły poruszające problem dużej umieralności niemowląt zamieszczano w czasopiśmie również w następnych latach ${ }^{25}$. Podawano też dla porównania informacje dotyczące śmiertelności niemowląt $w$ innych krajach europejskich i pozaeuropejskich. Jak wynikało z prezentowanych zestawień, Polska znajdowała się w niechlubnej czołówce $^{26}$. Jednocześnie obawiano się, iż całej Europie grozi wyludnienie i apelowano, aby pomyśleć nie tylko o zwiększeniu przyrostu naturalnego, ale również szans na przeżycie niemowlą ${ }^{27}$.

\section{OPIEKA NAD DZIEĆMI I MŁODZIEŻĄ W WIEKU SZKOLNYM}

\section{TRUDNE WARUNKI ŻYCIA UBOGICH DZIECI I MŁODZIEŻY}

Ubodzy rodzice często nie mieli możliwości lub nie potrafili właściwie zadbać o zaspokojenie potrzeb swego potomstwa i stworzyć odpowiednich warunków dla jego rozwoju. Na początku lat 30. sytuacja materialna znacznej części rodzin była bardzo trudna. Dotyczyło to zarówno mieszkańców miast, jak i wsi. W numerze 1 z 1936 roku autor Kroniki donosił o sytuacji dzieci na Podkarpaciu, które spędzały zimę, siedząc całe dnie w łóżkach przykryte kocami, gdyż nie miały ubrań i butów, aby wyjść z domu i pójść do szkoły ${ }^{28}$. Edward Hryniewicz opisywał głód, będący udziałem wielu małych mieszkańców miast i wsi ${ }^{29}$. Inny publicysta tak pisał o klęsce głodu na Polesiu: „W niektórych szkołach [...] 90 procent dzieci wymaga natychmiastowego dożywiania, gdyż inaczej szkoła będzie się musiała zamknąć.

${ }^{24}$ Oceny, 1932, „Życie Dziecka”, nr 4, s. 186.

25 Umieralność niemowląt, 1935, „Życie Dziecka”, nr 11, s. 329; Umieralność niemowlat w miastach i na wsi, 1936, „Życie Dziecka”, nr 1, s. 29; Umieralność niemowląt i liczba dzieci w rodzinie, 1936, „Życie Dziecka”, nr 1, s. 30; Spadek urodzin w Polsce, 1937, „Życie Dziecka”, nr 2, s. 58.

${ }^{26}$ Kronika zagraniczna. Węgry. Opieka nad niemowlętami, 1934, „Życie Dziecka”, nr 12, s. 347; Umieralność dzieci w Polsce, 1937, „Życie Dziecka”, nr 3, s. 88.

${ }^{27}$ Coraz mniej dzieci. Europie grozi wyludnienie, 1937, „Życie Dziecka”, nr 11, s. 220; Trzeba zacząć myśleć o przyroście, 1937, „Życie Dziecka”, nr 12, s. 253.

${ }^{28}$ Na Podkarpaciu dzieci często nie mają ubrań, 1936, „Życie Dziecka”, nr 1, s. 27.

${ }^{29}$ E. Hryniewicz, 1937, Dziecko na wsi. „Życie Dziecka”, nr 6-7, s. 165-166. 
Dzieci chodzą w łachmanach" ${ }^{30}$. W wielu miejscowościach Polesia „w szkołach dzieci gromadzą się licznie, ale wtedy, gdy mają być rozdawane śniadania. [...] Porcja chleba, pięć dekagramów słoniny na pajdę, kubek kakao gorącego jak ukrop. Ponieważ nie wszystkie dzieci stać na odpowiednie naczynia, poprzynosiły miseczki. Klasa od razu zmienia się w jadalnię - Ci mali stołownicy nie zawsze jednak mają łyżki. Wtedy (aby prędzej, aby prędzej) gorący płyn żłopią wprost z miseczek... jak małe, strasznie głodne psiaczki... Nawet pani nauczycielka nie ma siły powiedzieć, żeby dzieci jadły przyzwoiciej..." ${ }^{31}$. Jan Czarnecki w 1937 roku ubolewał nad warunkami mieszkaniowymi większości rodzin chłopskich, gdzie w jednej izbie przebywała nie tylko cała rodzina, ale też żywy inwentarz: „Kultura mieszkaniowa wsi jest nader prymitywna. Wnętrze przeciętnego domu chłopskiego urąga najczęściej podstawowym postulatom higieny i estetyki. Izba wiejska pełni liczne i różnorodne funkcje; jest ona jednocześnie sypialnią, kuchnią, jadalnią, spiżarką, pokojem dziecinnym, kurnikiem, nawet niekiedy - chlewem, szczególnie w porze zimowej i w dniach słotnych staje się izba chłopska ożywionym ogniskiem ludzi i zwierząt całej zagrody, zarazem - najbardziej niehigienicznym i nieestetycznym punktem gospodarstwa wiejskiego. Wprost okropnie wygląda mieszkanie jednoizbowe - pełni bowiem rozliczne funkcje stałe i przypadkowe. Jest ono niejednokrotnie terenem hodowli kur, gołębi, królików, kaczek, zwłaszcza podczas zimy" ${ }^{32}$. Z badań przeprowadzonych na polecenie Sejmu przez Komisję Ankietową na przełomie lat 20. i 30. XX wieku wynikało, że niemal $60 \%$ ludności wiejskiej w Polsce mieszkało w budynkach jednoizbowych ${ }^{33}$. Jan Czarnecki zwracał uwagę na szkodliwy wpływ wspólnego spania kilkorga rodzeństwa w jednym łóżku, „które jest niewygodne, ułatwia infekcję, naraża łatwo na przeziębienie (niedokładne przykrycie, leżenie tuż przy zimnej ścianie itp.), wywołuje skarlenie organizmu, skrzywienie kręgosłupa, chorobliwą postawę fizyczną"34. Tym bardziej, że „Werko jest najczęściej zgnojone, rzadko - chyba odświętnie - wietrzone [...] słoma sporadycznie zmieniana. Łóżko takie zanieczyszcza doszczętnie powietrze izby, jest zbiornikiem bakteryj chorobotwórczych"35. Pożywienie dzieci mieszkających na wsi było przeważnie jednostajne i nie dostarczało im niezbędnych dla prawidłowego rozwoju składników. Wynikało to nie tylko z biedy i zapracowania rodziców, ale przede wszystkim z braku świadomości na temat zapotrzebowania

\footnotetext{
${ }^{30}$ Klęska głodu na Polesiu, 1936, „Życie Dziecka”, nr 4, s. 123.

31 Tamże, s. 122.

32 J. Czarnecki, 1937, Mieszkania rodzin wiejskich. „Życie Dziecka”, nr 6-7, s. 169.

33 E. Hryniewicz, Dziecko na wsi..., dz. cyt., s. 166.

34 J. Czarnecki, Mieszkania rodzin wiejskich ..., dz. cyt., s. 173.

35 Tamże, s. 172.
} 
młodych, rozwijających się organizmów na składniki odżywcze. Niewłaściwe żywienie dzieci było przyczyną wielu chorób i nieprawidłowości w rozwoju ${ }^{36}$.

$\mathrm{W}$ jeszcze gorszej sytuacji znajdowały się ubogie dzieci mieszkające w miastach, które dodatkowo miały utrudniony dostęp do świeżego powietrza, całe dnie spędzały na brudnych podwórkach i ulicach, bawiąc się w pobliżu rynsztoków $\mathrm{z}$ nieczystościami ${ }^{37}$. W rodzinach robotniczych rodzice całe dnie spędzali poza domem, pracując $\mathrm{w}$ fabrykach po kilkanaście godzin na dobę, więc dzieci same musiały zadbać o zaspokajanie swych potrzeb. Często chodziły głodne, zazwyczaj też $\mathrm{w}$ brudnych, zniszczonych ubraniach. Wiele $\mathrm{z}$ nich na skutek chronicznego głodu i przebytych chorób nie rozwijało się prawidłowo. Na problemy dzieci ze środowisk robotnych zwrócił uwagę Józef Tadeusz Mieszkowski ${ }^{38}$. Teodor Toeplitz wskazywał na trudne warunki mieszkaniowe ubogich rodzin miejskich i konieczność uwzględnienia potrzeb dzieci (miejsc do zabaw dziecięcych, boisk i parków) w planowaniu zabudowy miast ${ }^{39}$. Robotnicy i niżsi urzędnicy państwowi wraz ze swymi rodzinami mieszkali zazwyczaj na poddaszach, w dusznych, niewietrzonych, ciasnych izbach, w których największe, a czasem jedyne pomieszczenie stawało się ośrodkiem życia całej rodziny i pełniło różne funkcje: kuchni, jadalni, pralni, pokoju dziecinnego. Brak miejsca do odrabiania lekcji i przechowywania przyborów szkolnych skutkował często złymi ocenami w szkole. Dzieci przeważnie zawadzały w domu, naprzykrzając się innym. Gdy tylko nadarzała się okazja, uciekały na podwórko lub ulicę. Maria Nowicka-Rapacka zwracała uwagę, że brak czasu, cierpliwości i zrozumienia dla własnych dzieci oraz niemożność zaspokojenia ich potrzeb powodują poważne braki w ich rozwoju fizycznym i duchowym ${ }^{40}$.

\section{DOŻYWIANIE UCZNIÓW}

W szkołach powszechnych, do których uczęszczały dzieci z uboższych rodzin, wielu uczniów było chronicznie niedożywionych i osłabionych z powodu złych warunków mieszkaniowych. Niewłaściwie zorganizowana praca w szkole, przeciążenie nauką, zbyt mało zajęć ruchowych pogłębiały istniejące już problemy zdrowotne i przyczyniały się do powstawania nowych. Dlatego na łamach „Życia

${ }^{36}$ J. Czarnecki, 1937, Odżywianie dzieci wiejskich. „Życie Dziecka”, nr 3, s. 70.

37 E. Hryniewicz, 1937, Dzieci biedoty miejskiej. „Życie Dziecka”, nr 5, s. 131.

38 J.T. Mieszkowski, 1933, Dola dziecka robotniczego w Polsce w świetle cyfr i „Pamiętników Bezrobotnych”. „Życie Dziecka”, nr 2, 43; nr 3, s.82.

39 T. Toeplitz, 1933, Dziecko w planie miasta. „Życie Dziecka”, nr 4-5, s. 97.

${ }^{40}$ M. Nowicka-Rapacka, 1937, Dzieci przedmieścia w świetlicy eksperymentalnej. „Życie Dziecka”, nr 11, s. 230-231. 
Dziecka" apelowano do społeczeństwa o większe zainteresowanie losem uczniów szkół powszechnych i otoczenie ich opieką. Istotne było zorganizowanie dożywiania zarówno w szkołach, jak i w innych miejscach, które można było w tym celu wykorzystać. W czasopiśmie apelowano do władz miejskich oraz ludzi dobrej woli o gromadzenie funduszy i organizację akcji dożywiania ${ }^{41}$. Informowano też o potrzebie zapewnienia ubogim dzieciom odzieży i miejsca do odrabiania lekcji ${ }^{42}$ oraz o działaniach podejmowanych na rzecz poprawy sytuacji uczniów z najuboższych rodzin ${ }^{43}$. W 1937 roku w samej tylko Warszawie z bezpłatnych posiłków skorzystało 36 tys. uczniów ${ }^{44}$. Do udziału w akcji dożywiania Minister Opieki Społecznej Stefan Hubicki zobowiązał również świetlice, „w miarę możności lokalowych i organizacyjnych oraz warunków danego terenu”45. W 1937 roku profesor Mieczysław Michałowicz, dyrektor jednej z klinik dziecięcych, wziął udział w zorganizowanej w Genewie konferencji, poświęconej dożywaniu dzieci i młodzieży ${ }^{46}$.

\section{ĆWICZENIA FIZYCZNE, HIGIENA CIAŁA I SZCZEPIENIA OCHRONNE}

Lekarze i działacze społeczni doceniali też znaczenie sportu i ćwiczeń fizycznych dla prawidłowego rozwoju dzieci i młodzieży ${ }^{47}$. Tadeusz Chrapowicki podkreślał wychowawczą rolę gier i zabaw ruchowych ${ }^{48}$. A. Siurbis apelował o tworzenie nowych boisk szkolnych ${ }^{49}$. W 1936 roku w czasopiśmie ogłoszono zbiórkę sprzętu sportowego od firm i osób prywatnych dla szkół powszechnych na wsi i w małych

${ }^{41}$ Czy znajda się fundusze na dożywianie w szkołach, 1935, „Życie Dziecka”, nr 10, s. 293.

${ }^{42}$ Jakie braki musi usunąć pomoc społeczna dla dzieci stolicy, 1937, „Życie Dziecka”, nr 1, s. 22; Akcja dożywiania dzieci zagrożona, 1936, „Życie Dziecka”, nr 3, s. 92.

${ }^{43}$ St. Gutentag, 1933, O dokarmianiu dzieci w szkołach publicznych miasta Łodzi. „Życie Dziecka”, nr 10, s. 275-277; Rada szkolna roztoczyła opiekę nad zaniedbanymi dziećmi, 1935, „Życie Dziecka”, nr 10, s. 294; Bony na dożywianie dzieci, 1936, „Życie Dziecka”, nr 3, s. 92; Akcja dożywiania dzieci stolicy, 1937, „Życie Dziecka”, nr 1, s. 20; Pomoc zimowa, 1937, „Życie Dziecka”, nr 11, s. 219; Dożywianie dzieci, 1937, „Życie Dziecka”, nr 4, s. 121.

${ }_{44} 36$ tys. dzieci warszawskich korzystało $z$ dożywiania, 1937, „Życie Dziecka”, nr 10, s. 184.

${ }_{45}$ Pismo okólne Ministerstwa Opieki Społecznej z dnia 13 stycznia 1933 r. Nr 41/O.M. w sprawie akcji świetlicowej, 1934, „Życie Dziecka”, nr 5, s. 165.

${ }^{46}$ Delegacja na konferencje w sprawie odżywiania dzieci (Genewa), 1937, „Życie Dziecka”, nr 1, s. 27.

47 T. Chrapowicki, 1933, Nowe programy ćwiczeń cielesnych w szkolnictwie. „Życie Dziecka”, nr 11-12, s. 317-326.

${ }_{48}$ T. Chrapowicki, 1933, Gry i zabawy jako czynnik wychowawczy. „Życie Dziecka”, nr 4-5, s. $119-127$.

49 A. Siurbis, 1937, Nadać tempo powszechnej akcji boiskowej dla dzieci w Polsce. „Życie Dziecka”, nr 4, s. 108. 
miasteczkach. Zbiórkę zorganizował Referat Sportowy Polskiego Radia. Dzięki tej akcji w ciągu 2 lat w sprzęt sportowy wyposażono 60 szkół. Była to jednak kropla w morzu potrzeb, dlatego publicyści apelowali do czytelników o finansowe wspieranie tej akcji w środowiskach lokalnych ${ }^{50}$. W czasopiśmie informowano też o zorganizowaniu w Warszawie kąpieli dla uczniów, które miały na celu podniesienie świadomości higienicznej dzieci i młodzieży oraz stworzenie warunków do praktykowania pożądanych zachowań ${ }^{51}$.

W dużych skupiskach ludności żyjącej w trudnych warunkach sanitarnych istotną rolę odgrywały szczepienia ochronne. Na łamach „Życia Dziecka” informowano o znaczeniu i sposobie działania szczepionek. Zachęcano rodziców do szczepienia dzieci, czasami informowano o przymusie w tym zakresie. Przestrzegano też przed zagrożeniami, jakie niesie za sobą rezygnacja ze szczepień ochronnych ${ }^{52}$.

PRZECIWDZIAŁANIE ALKOHOLIZMOWI DZIECI I MŁODZIEŻY

Czynnikiem zagrażającym prawidłowemu rozwojowi już nawet kilkuletnich dzieci było spożywanie alkoholu. Alkoholem częstowano przyjaciół i znajomych podczas wszystkich ważnych uroczystości rodzinnych. Piwo oraz inne alkohole podawano nawet małym dzieciom, nie widząc w tym niczego złego. Czasami wódką z cukrem uspokajano płaczące niemowlęta oraz usypiano małe dzieci, gdy ich matka musiała iść na pole lub zająć się gospodarstwem. Tymczasem spożywane dość często napoje alkoholowe nie tylko uzależniały, ale też czyniły poważne spustoszenia $\mathrm{w}$ organizmie, niejednokrotnie hamując rozwój fizyczny i umysłowy dziecka ${ }^{53}$. Również wśród uczniów, zwłaszcza szkół powszechnych, spożywanie alkoholu było częstym zjawiskiem. Dlatego na łamach „Życia Dziecka” niejednokrotnie apelowano do rodziców i nauczycieli o zwalczanie zgubnego nałogu pijaństwa wśród młodego pokolenia oraz informowano o podejmowanych w szkołach działaniach, mających na celu propagowanie trzeźwości ${ }^{54}$. Za najbardziej skuteczne sposoby oddziaływań lekarze i publicyści uznawali dawanie dzieciom i młodzieży dobrego przykładu przez dorosłych, zwłaszcza osoby ważne w ich życiu oraz propagowanie trzeźwości,

${ }^{50}$ Akcja zbierania sprzętu sportowego dla szkół powszechnych, 1936, „Życie Dziecka”, nr 1, s. 26.

${ }^{51}$ Kapiele dla dzieci szkolnych $w$ Warszawie, 1936, „Życie Dziecka”, nr 11, s. 301.

52 Koklusz, 1936, „Życie Dziecka”, nr 1, s. 26; Przymusowe szczepienia, 1936, „Życie Dziecka”, nr 5, s. 153; J. Stein, 1937, Przeciwgruźlicze szczepienia ochronne BCG. „Życie Dziecka”, nr 1, s. 12; Przymusowe szczepienie ospy, 1937, „Życie Dziecka”, nr 5, s. 157.

${ }_{53}$ Alkoholizm wśród dzieci, 1935, „Życie Dziecka”, nr 9, s. 264; Alkoholizm sieje spustoszenie wśród najmłodszego pokolenia, 1937, „Życie Dziecka”, nr 2, s. 59.

${ }^{54}$ Zwalczanie alkoholizmu wśród młodzieży szkolnej, 1936, „Życie Dziecka”, nr 1, s. 25; Zastraszający nałóg wśród dzieci, 1936, „Życie Dziecka”, nr 8-9, s. 229. 
zarówno w szkole, jak i w środowisku zamieszkania ${ }^{55}$. Doceniając powagę sytuacji organizacje zajmujące się walką z alkoholizmem oraz różne instytucje kulturalne i oświatowe, podejmowały działania mające na celu „uświadomić społeczeństwu konieczność ochrony rodziny przed tym niedocenianym wrogiem jej szczęścia i prawidłowego rozwoju" 56 .

\section{ORGANIZOWANIE KOLONII I PÓŁKOLONII \\ DLA DZIECI I MŁODZIEŻY SZKOLNEJ}

Aby ograniczyć wpływ szkodliwych warunków życia na rozwój dzieci, w okresie wakacyjnym organizowano kolonie. Organizatorzy stawiali sobie za cel danie dzieciom zdrowego, posilnego pożywienia, możliwości pobytu na świeżym powietrzu i odpoczynku. Ze sprawozdań opiekunów kolonijnych wynikało, że chociaż czterotygodniowe kolonie na wsi nie zlikwidowały wszystkich problemów zdrowotnych uczestników, niewątpliwie poprawiły ich kondycję fizyczną i w pewnym stopniu uodporniły na niekorzystne wpływy środowiska zamieszkania. Oczywiście zdawano sobie sprawę, że miesięczny pobyt na wsi nie zmieniał diametralnie sytuacji dzieci, które po tym czasie wracały do domu rodzinnego i warunków, w jakich wychowywały się przed wyjazdem na kolonie. Mimo to starano się w jak największym stopniu wykorzystać pobyt dzieci na wsi, aby przybrały na wadze, wypoczęly, a w kontakcie z przyrodą bliżej poznały otaczający świat. Stąd przywiązywano dużą uwagę do właściwego doboru opiekunów zatrudnianych na koloniach oraz wyboru miejscowości przeznaczonych dla dzieci. Na kolonie letnie wysyłano dzieci słabe i chorowite, potrzebujące natychmiastowego „zabrania” z niekorzystnych warunków mieszkaniowych. Na początku lat 30. na kolonie mogła wyjechać stosunkowo niewielka grupa dzieci, dlatego przeprowadzano dokładną selekcję. W następnych latach akcja kolonijna rozwijała się, włączały się do niej różne organizacje i instytucje. Wówczas więcej dzieci mogło skorzystać $\mathrm{z}$ tej formy wypoczynku i wzmocnienia ${ }^{57}$.

Jeden z publicystów „Życia Dziecka” w 1933 roku zachęcał do organizowania kolonii zimowych, wskazując na ich rolę w kształtowaniu prawidłowych nawyków higienicznych: „mogą wywrzeć dobry wpływ na dzieci przyzwyczajone do dusznych, nie przewietrzanych mieszkań proletariackich, do noszenia stale grubych trykotów - tu gimnastykują się nago przy otwartych oknach, przez które wpada

${ }_{55}$ Propaganda trzeźwości, 1932, „Życie Dziecka”, nr 8-9, s. 309.

56 Tydzień propagandy trzeźwości, 1936, „Życie Dziecka”, nr 1, s. 25.

${ }^{57}$ Kolonie i półkolonie letnie organizuje Komitet Pomocy Dzieciom, 1937, „Życie Dziecka”, nr 5, s. 158. 
świeże, mroźne powietrze - uczą się, że można nawet przy braku łazienki umyć się od stóp do głów; bardzo szybko przestają bać się nacierania czy zlewania zimną wodą" 58 .

Dla dzieci zagrożonych chorobą lub rekonwalescentów organizowano kolonie zdrowotne. O koloniach dla dzieci zagrożonych gruźlicą pisała Maria Skokowska-Rudolfowa ${ }^{59}$. Pobyt na czterotygodniowych koloniach przeciwgruźliczych w Miłośnie, Urlach, Nowym Mieście i Otwocku w 1933 roku Józef Czesław Babicki scharakteryzował następująco: „Kolonie lecznicze mają teraz charakter naprawdę leczniczy, mieszczą się w miejscowościach klimatycznych, w specjalnych pawilonach, korzystają z opieki lekarskiej i zabiegów leczniczych"60.

Ponieważ jednak pobyt na koloniach letnich, zimowych i leczniczych był stosunkowo drogi, wyjazdy organizowano głównie dla dzieci słabszych i chorych. Od 1936 roku dla uczniów cieszących się nieco lepszym zdrowiem, którzy również potrzebowali wypoczynku w okresie wolnym od szkoły, a ich ubodzy rodzice nie mogli sobie pozwolić na wyjazd syna lub córki poza miasto, zaczęto organizować półkolonie ${ }^{61}$. Była to forma znacznie tańsza od poprzedniej. Dzieci wracały na noc do domu, natomiast w ciągu dnia uczestniczyły w różnych zajęciach. Publicysta informował czytelników: „Na zorganizowanie półkolonii miasto dostarczy odpowiednich terenów. Do tego celu zostaną użyte wszystkie ogrody i parki miejskie, a nawet ogrody prywatne [...]. Na półkoloniach dzieci korzystać będą z opieki fachowych instruktorów, z pomocy higienicznej i lekarskiej. Ponadto na miejscu prowadzona będzie akcja kulturalno-wychowawcza. Dzieci otrzymywać będą kilka razy dziennie posiłek" 62 . Jednocześnie publicyści podkreślali, że prawo do udziału w półkoloniach oraz w koloniach wypoczynkowych powinien mieć każdy uczeń ${ }^{63}$. W tym celu należało zapewnić dzieciom i młodzieży dostęp do większej niż dotąd ilości terenów zielonych ${ }^{64}$. Ważną rolę odgrywały zwłaszcza ogrody jordanowskie, w których zapewniano uczestnikom zajęć nie tylko możliwość rozwoju fizycznego i organizację czasu wolnego, ale też opiekę lekarską ${ }^{65}$.

${ }^{58}$ Zagadnienie kolonii zimowych, 1934, „Życie Dziecka”, nr 11, s. 318.

59 M. Skokowska-Rudolfowa, 1933, O roli kolonii leczniczych $w$ zwalczaniu gruźlicy. „Życie Dziecka”, nr 9, s. 250-256.

${ }^{60}$ Przegląd piśmiennictwa. J. Cz. Babicki: Kolonie letnie w 1933 r., 1935, „Życie Dziecka”, nr 5-6, s. 176.

${ }^{61}$ M. Roszkowska, 1935, Półkolonie letnie. „Życie Dziecka”, nr 5-6, s. 136-145; Akcja pótkolonijna w stolicy, 1937, „Życie Dziecka”, nr 6-7, s. 201; Półkolonie dla dzieci warszawskich, 1937, „Życie Dziecka”, nr 10, s. 184.

62 Wypoczynek letni dla najuboższych dzieci Warszawy. We wszystkich ogrodach i parkach organizowane będa półkolonie letnie, 1935, „Życie Dziecka”, nr 5-6, s. 166.

${ }_{63}$ Wszystkie dzieci w Polsce mogłyby jechać na kolonie, 1936, „Życie Dziecka”, nr 6-7, s. 194.

${ }^{64}$ Więcej terenów dla dzieci, 1937, „Życie Dziecka”, nr 12, s. 254.

${ }^{65}$ J. Bogdanowicz, 1933, Opieka lekarska w ogródku jordanowskim. „Życie Dziecka”, nr 9, s. 259. 
Zwracano też uwagę, że nawet najprzyjemniej spędzony w okresie wakacyjnym czas i osiągnięta w tym czasie poprawa stanu zdrowia dziecka nie wystarczą, jeśli $\mathrm{w}$ kolejnych miesiącach rodzice $\mathrm{z}$ różnych powodów, zwłaszcza trudnej sytuacji materialnej, nie będą mogli zapewnić dziecku właściwych warunków rozwoju. Zniweczony wówczas zostanie cały trud organizatorów i opiekunów kolonijnych. Dlatego domagano się, aby akcję pomocy dzieciom $\mathrm{z}$ rodzin najuboższych rozciągnąć też na pozostałe miesiące roku. Zaczęto więc organizować różnego rodzaju świetlice ${ }^{66}$, informowano o ogrodach jordanowskich ${ }^{67}$, podkreślano konieczność rozwijania akcji boiskowej ${ }^{68}$.

Domagano się też tworzenia kolonii letnich lub półkolonii dla dzieci wiejskich. Również na wsi warunki życia były trudne. Rodzice całe dnie pracowali w polu, natomiast ich kilkuletnie dzieci pozostawały bez opieki. Brak nadzoru ze strony osób dorosłych kończył się dość często śmiercią lub kalectwem dziecka. Domagano się organizowania dla dzieci wiejskich kolonii letnich w miastach, aby „zetknęły się z przejawami kultury wielkomiejskiej”, aby umożliwić im „przeżycie dzieciństwa radosne, szerokie spojrzenie na świat, wniesienie w środowisko wiejskie nowych horyzontów - wartościowego stylu współżycia"69. Apelowano do mieszkańców dworów szlacheckich i bogatych ziemian, aby organizowali opiekę nad dziećmi chłopskimi, zwłaszcza w okresie nasilonych prac polowych.

\section{ZAKOŃCZENIE}

W latach 30. XX wieku władze II Rzeczypospolitej nie potrafiły poradzić sobie z przezwyciężeniem wielu problemów społeczno-ekonomicznych, z którymi borykała się znaczna część społeczeństwa. Dlatego też konieczne były działania oddolne, organizowane w środowisku lokalnym. Ich realizacja była możliwa dzięki zaangażowaniu ludzi dobrej woli, wrażliwych na potrzeby drugiego człowieka. Jednak nie wszyscy uświadamiali sobie istniejące potrzeby i możliwości włączenia się w działania opiekuńcze i pomocowe. Dlatego tak ważna była działalność redakcji i publicystów czasopism, którzy uświadamiali ogółowi społeczeństwa istniejące potrzeby oraz wskazywali kierunki możliwych działań. Niewątpliwie jednym z najważniejszych problemów była kwestia wychowania młodego pokolenia oraz zapewnienia dzieciom i młodzieży jak najlepszych warunków życia na

${ }^{66}$ Działalność świetlicowa P.M.S., 1937, „Życie Dziecka”, nr 12, s. 254.

${ }^{67}$ Kronika krajowa. Jeszcze jeden ogródek jordanowski, 1935, „Życie Dziecka”, nr 9, s. 264.

${ }^{68}$ A. Siurbis, Nadać tempo..., s. 108.

${ }^{69} \mathrm{~J}$. Czarnecki, 1935, Wiejskie dzieci rodziców bezrolnych i małorolnych, a akcja kolonijna. „Życie Dziecka”, nr 7-8, s. 210. 
miarę możliwości środowiska, w którym wzrastali. Apele redakcji i publicystów czasopism oraz publikujących na ich łamach lekarzy i pedagogów oraz innych działaczy społecznych przynosiły rezultaty, o czym świadczy choćby rozwinięta na szeroką skalę akcja kolonijna. „Życie Dziecka” pełniło też funkcję edukacyjną, ucząc społeczeństwo, a zwłaszcza matki, jak właściwie zaspokajać potrzeby potomstwa, informując o pojawiających się zagrożeniach i sposobie ich przezwyciężania. Odegrało więc ważną rolę społeczną, przyczyniając się do poprawy sytuacji młodego pokolenia.

\section{LITERATURA}

36 tys. dzieci warszawskich korzystało z dożywiania, 1937, „Życie Dziecka”, nr 10, 184. Akcja dożywiania dzieci stolicy, 1937, „Życie Dziecka”, nr 1, 20.

Akcja dożywiania dzieci zagrożona, 1936, „Życie Dziecka”, nr 3, 92.

Akcja półkolonijna w stolicy, 1937, „Życie Dziecka”, nr 6-7, 201.

Akcja zbierania sprzętu sportowego dla szkót powszechnych, 1936, „Życie Dziecka”, nr 1, 26.

Alkoholizm sieje spustoszenie wśród najmłodszego pokolenia, 1937, „Życie Dziecka”, nr 2, 59-60.

Alkoholizm wśród dzieci, 1935, „Życie Dziecka”, nr 9, 264.

Balcerek M., 1978, Rozwój opieki nad dzieckiem w Polsce w latach 1918-1939. Warszawa, PWN.

Bogdanowicz J., 1933, Opieka lekarska w ogródku jordanowskim. „Życie Dziecka”, nr 9, 259-261.

Bogdanowicz J., 1934, Opieka nad dzieckiem do jego urodzenia, „Życie Dziecka”, nr 10-11, 307-309.

Bony na dożywianie dzieci, 1936, „Życie Dziecka”, nr 3, 92.

Chrapowicki T., 1933, Gry i zabawy jako czynnik wychowawczy. „Życie Dziecka”, nr 4-5, 119-127.

Chrapowicki T., 1933, Nowe programy ćwiczeń cielesnych w szkolnictwie. „Życie Dziecka”, nr 11-12, 317-326.

Cieszyński F., 1933, Położna jako wiejska opiekunka zdrowia matki i dziecka. „Życie Dziecka", nr 9, 242-249.

Coraz mniej dzieci. Europie grozi wyludnienie, 1937, „Życie Dziecka”, nr 11, 220.

Czarnecki J., 1937, Mieszkania rodzin wiejskich. „Życie Dziecka”, nr 6-7, 169-178.

Czarnecki J., 1937, Odżywianie dzieci wiejskich. „Życie Dziecka”, nr 3, 70-75.

Czarnecki J., 1935, Wiejskie dzieci rodziców bezrolnych i małorolnych, a akcja kolonijna. „Życie Dziecka”, nr 7-8, 208-211. 
Czy znajdą się fundusze na dożywianie w szkołach, 1935, „Życie Dziecka”, nr 10, 293-294. Delegacja na konferencje w sprawie odżywiania dzieci (Genewa), 1937, „Życie Dziecka”, nr 1, 27.

Dożywianie dzieci, 1937, „Życie Dziecka”, nr 4, 121.

Działalność świetlicowa P.M.S., 1937, „Życie Dziecka”, nr 12, 254.

Eksperyment dotyczący szkolenia rodziców w pojmowaniu zagadnień odżywiania dzieci (St. Zjedn.), 1936, „Życie Dziecka”, nr 4, 127-128.

Friedlanderowa L., 1934, Błędy wychowawcze matek. „Życie Dziecka”, nr 10-11, 310-316. Gutentag St., 1933, O dokarmianiu dzieci w szkołach publicznych m. Łodzi. „Życie Dziecka", nr 10, 275-277.

Hryniewicz E., 1937, Dzieci biedoty miejskiej. „Życie Dziecka”, nr 5, 131-138.

Hryniewicz E., 1937, Dziecko na wsi. „Życie Dziecka”, nr 6-7, 163-168.

Jakie braki musi usunąć pomoc społeczna dla dzieci stolicy, 1937, „Życie Dziecka”, nr 1, 22.

Kabzińska Ł., Kabziński K., 2012, Wybrane aspekty zagrożonego dzieciństwa $w$ dwudziestoleciu międzywojennym. „Warmińsko-Mazurski Kwartalnik Naukowy. Nauki Społeczne", nr 4, 11-43.

Kąpiele dla dzieci szkolnych w Warszawie, 1936, „Życie Dziecka”, nr 11, 301.

Klęska głodu na Polesiu, 1936, „Życie Dziecka”, nr 4, 122-123.

Koklusz, 1936, „Życie Dziecka”, nr 1, 26.

Kolonie i półkolonie letnie organizuje Komitet Pomocy Dzieciom, 1937, „Życie Dziecka”, nr 5, 158.

Konkurs na pogadankę z rodzicami: Co daje stacja opieki matce i dziecku, 1932, „Życie Dziecka”, nr 1, 53-54.

Kronika krajowa. Jeszcze jeden ogródek jordanowski, 1935, „Życie Dziecka”, nr 9, 264. Kronika zagraniczna. Węgry. Opieka nad niemowlętami, 1934, „Życie Dziecka”, nr 12, 347-348.

Kurs p.n. „Kobieta w rodzinie”, 1937, „Życie Dziecka”, nr 3, 87.

Maria, 1932, Pogadanka o odżywianiu niemowlęcia. „Życie Dziecka”, nr 1, 40-52.

Michałowicz M., 1932, Na nowe drogi. „Życie Dziecka”, nr 1, 1-2.

Mieszkowski J.T., 1933, Dola dziecka robotniczego w Polsce w świetle cyfr $i$ „Pamiętników bezrobotnych”. „Życie Dziecka”, nr 2, 43-51; nr 3, 82-92.

Na Podkarpaciu dzieci często nie mają ubrań, 1936, „Życie Dziecka”, nr 1, 27.

Nowa Stacja Opieki nad Matka i Dzieckiem w Sosnowcu, 1937, „Życie Dziecka”, nr 1, 20. Nowicka-Rapacka M., 1937, Dzieci przedmieścia w świetlicy eksperymentalnej. „Życie Dziecka", nr 11, 225-244.

Oceny, 1932, „Życie Dziecka”, nr 4, 186.

Opieka nad macierzyństwem szwankuje. ZSRR, 1937, „Życie Dziecka”, nr 1, 28-29.

Opieka nad matka i dzieckiem. Anglia, 1937, „Życie Dziecka”, nr 4, 128-129.

Opieka nad młodzieżą i dziećmi, 1926, „Praca i Opieka Społeczna”, z. 1-2. 
Piekarski C., 1934, Opieka społeczna nad matką i dzieckiem na wsi. „Życie Dziecka”, nr 6, 169-174.

Pismo okólne Ministerstwa Opieki Społecznej z dnia 13 stycznia 1933 r. Nr 41/O.M. w sprawie akcji świetlicowej, 1934, „Życie Dziecka”, nr 5, 165-166.

Pomoc zimowa, 1937, „Życie Dziecka”, nr 11, 219-220.

Poradnie odżywcze i ochronki. ZSRR, 1936, „Życie Dziecka”, nr 4, 127.

Półkolonie dla dzieci warszawskich, 1937, „Życie Dziecka”, nr 10, 184.

Półkolonie, 1936, „Życie Dziecka”, nr 10, 268.

Prace nad ustawa o opiece nad macierzyństwem, dziećmi i młodzieża, 1936, „Życie Dziecka”, nr 8-9, 233.

Propaganda trzeźwości, 1932, „Życie Dziecka”, nr 8-9, 309-310.

Przegląd piśmiennictwa. J. Cz. Babicki: Kolonie letnie w 1933 r., 1935, „Życie Dziecka”, nr 5-6, 176.

Przymusowe szczepienia, 1936, „Życie Dziecka”, nr 5, 153.

Przymusowe szczepienie ospy, 1937, „Życie Dziecka”, nr 5, 157.

Rada szkolna roztoczyła opiekę nad zaniedbanymi dziećmi, 1935, „Życie Dziecka”, nr 10, 294.

Redakcja i Administracja, Zmiana tytułu „Życia Dziecka”, 1937, „Życie Dziecka”, nr 11, 224.

Roszkowska M., 1935, Półkolonie letnie. „Życie Dziecka”, nr 5-6, 136-145.

Siostra M., 1932, Po co przychodzę z dzieckiem do poradni. „Życie Dziecka”, nr 1, 27-39.

Siurbis A., 1937, Nadać tempo powszechnej akcji boiskowej dla dzieci w Polsce. „Życie Dziecka”, nr 4, 108-110.

Skokowska-Rudolfowa M., 1933, O roli kolonii leczniczych $w$ zwalczaniu gruźlicy. „Życie Dziecka”, nr 9, 250-256.

Spadek urodzin w Polsce, 1937, „Życie Dziecka”, nr 2, 58.

Stan fizyczny dzieci w szkołach londyńskich, 1937, „Życie Dziecka”, nr 1, 28.

Stein J., 1937, Przeciwgruźlicze szczepienia ochronne BCG. „Życie Dziecka”, nr 1, 12-15.

Stoffowa E., 1932, Powstanie, organizacja i praca Stacji Opieki nad Matka i Dzieckiem we Lwowie. „Życie Dziecka”, nr 3, 125-131.

Trzeba zacząć myśleć o przyroście. „Życie Dziecka” 1937, nr 12, 253.

Toeplitz T., 1933, Dziecko w planie miasta. „Życie Dziecka”, nr 4-5, 97-105.

Tydzień propagandy trzeźwości, 1936, „Życie Dziecka”, nr 1, 25.

Umieralność dzieci w Polsce, 1937, „Życie Dziecka”, nr 3, 88.

Umieralność niemowląt, 1935, „Życie Dziecka”, nr 11, 329.

Umieralność niemowląt i liczba dzieci w rodzinie, 1936, „Życie Dziecka”, nr 1, 30.

Umieralność niemowląt w miastach i na wsi, 1936, „Życie Dziecka”, nr 1, 29.

Ustawa z dnia 16 sierpnia 1923 r. o opiece społecznej. Dz. U. 1923, nr 92, poz. 726.

Wiek matki i okresy czasu między kolejnymi porodami, 1936, „Życie Dziecka”, nr 1, 30. 
Więcej terenów dla dzieci, 1937, „Życie Dziecka”, nr 12, 254.

Wszystkie dzieci w Polsce mogłyby jechać na kolonie, 1936, „Życie Dziecka”, nr 6-7, 194. Wypoczynek letni dla najuboższych dzieci Warszawy. We wszystkich ogrodach i parkach

organizowane będa półkolonie letnie, 1935, „Życie Dziecka”, nr 5-6, 166-167.

Z działalności Stacji Opieki nad Matka i Dzieckiem w Chełmży z roku 1931, 1932, „Życie Dziecka”, nr 2, 94-95.

Zagadnienie kolonii zimowych, 1934, „Życie Dziecka”, nr 11, 317-319.

Zastraszający nałóg wśród dzieci, 1936, „Życie Dziecka”, nr 8-9, 229.

Zwalczanie alkoholizmu wśród młodzieży szkolnej, 1936, „Życie Dziecka”, nr 1, 25.

\author{
CUSTODY FOR HEALTH AND PROPER PHYSICAL DEVELOPMENT \\ OF CHILDREN ON COLUMNS OF THE JOURNAL „ŻYCIE DZIECKA” \\ FROM PERIOD 1932-1937
}

\begin{abstract}
The aim of this article is to show publicists' views of necessity to look after children from the poorest families in the journal „Życie Dziecka” realised since 1932 till 1937. To collect data it was used the method of analysis of the press content. „Życie Dziecka” (The Child's Life) - it was „a journal devoted to maternity protection, care for children and youth and child's life". The magazine was publishing in 1930s. The Polish state revived after 123 years of captivity was still backward and socially mixed. In addition the Great Depression caused worsening of material conditions of goodly part of society. The children of the poorest social stratum: working-class, peasant class were in the most difficult situation. They required help because they were underfed, neglected, toiling in farm, physically poorly developed, often ill. Parents didn't have possibility to satisfy children's needs so it was necessary to involve wider social circles and organize the necessary support. These issues were discussed on the journal's columns. It was made efforts to aware to society of necessity to organize custody and support for the most necessitous people. It was being written about taken actions in this field.
\end{abstract}

Keywords: custody of children, summer camps for children, social care, danger to children's development 